\title{
Analysis viscoelastic properties of fiber- reinforced composite spring for the all-terrain vehicle
}

\author{
Kirill B. Evseev ${ }^{1, *}$, Aleksander B. Kartashov ${ }^{1}$, Idris Z. Dashtiev ${ }^{1}$, and Aleksey V. Pozdeev ${ }^{2}$ \\ ${ }^{1}$ Bauman Moscow State Technical University, Baumanskaya 2-ya, 5/1, Moscow, Russia, 105005 \\ ${ }^{2}$ Volgograd State Technical University, Russia, Lenin, 28, Volgograd, Russia, 28400005
}

\begin{abstract}
For today's composite materials have many advantages over steel materials. The composite materials take the main part in modern automobile constructions. Suspension system is the main automobile part. Components of suspension system are made of metal. Therefor suspension system have a high weight that have a negative effect for all of vehicle especially for vehicle dynamics and stability properties. The main part of suspension system is a spring element. Coil springs are the most widely used spring type for independent wheel suspension for trucks and passengers vehicles. Using composite springs can less vehicle weight especially less unspring masses. It is one of the main features of composite materials. Another feature is viscoelastic properties and hysteresis effect. That can be give excellent noise and vibration properties for vehicles.
\end{abstract}

\section{Introduction}

The material of composite coil spring have a complicated structure - fiber reinforced layers are combines with epoxy resin. This material have different mechanical properties in different directions. Therefor the analysis mechanical properties of composite coil spring needs a lot of engineering work and experimental work firstly. Mechanical properties of multiaxial structure of composite spring material cannot be calculation with using standard analytical methods [1]. Designing the composite spring is difficult for engineers. Experimental work is determinate the mechanical properties of composite coil springs and material properties. Material properties can using later for the finite-element calculations by explorers.

The composite spring material has viscoelastic properties that are interesting for researchers, so in this article is described analysis these properties by the test bench and determined the value of the dissipated composite spring energy.

Composite coil spring (Figure 1) for the experimental work was made from fiber-glass composite material [2-4]. It is cheap and strong material. The shock absorber assembly with composite spring is shown in the Figure 1.

\footnotetext{
*Corresponding author: kb evseev@,bmstu.ru
} 


\section{- NETHIII Do}

Fig. 1. Fiber-glass coil composite spring with shock absorber.

Composite spring and shock absorber are apply in front and rear independent suspension on all-terrain vehicle (ATV) [5] BRP Can-Am Outlander 800R X-MR EFI. Steel spring and composite spring design parameters are given in the Table 1.

Table 1. Compare steel spring and composite spring design parameters.

\begin{tabular}{|c|c|c|}
\hline Design parameter & Steel spring & Composite spring \\
\hline Spring stiffness & $25 \frac{\mathrm{N}}{\mathrm{mm}}$ & $25 \frac{\mathrm{N}}{\mathrm{mm}}$ \\
\hline Wire diameter & $10 \mathrm{~mm}$ & $15.7 \mathrm{~mm}$ \\
\hline Free length & $340 \mathrm{~mm}$ & $340 \mathrm{~mm}$ \\
\hline Maximum shear & $170 \mathrm{~mm}$ & $170 \mathrm{~mm}$ \\
\hline Number of active coils & 9.5 & 8 \\
\hline Inside diameter & $55 \mathrm{~mm}$ & $56 \mathrm{~mm}$ \\
\hline Spring mass & $1.19 \mathrm{~kg}$ & $0.76 \mathrm{~kg}$ \\
\hline
\end{tabular}

If we compare steel spring and composite spring we find that for the same stiffness, free length and maximum shear stress composite spring are lighter more than $30 \%$. This difference increases up to $80 \%$ for heavy trucks suspension springs.

\section{Experimental work}

Scientific research work was complete on servo-hydraulic test bench designed and assembled in Volgograd State Technical University (VSTU) [6-9]. Servo-hydraulically test bench is shown in the Figure 2.

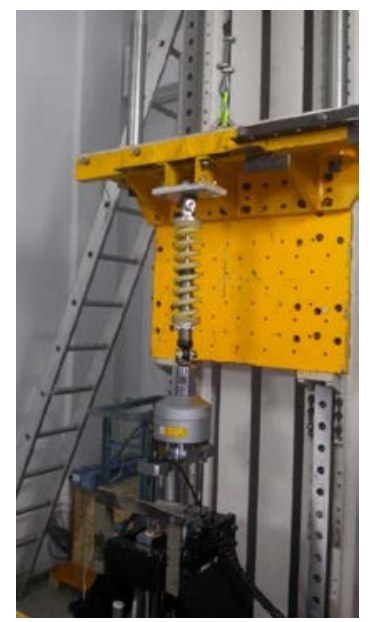

Fig. 2. Servo-hydraulically test bench with composite spring and shock absorber. 
The major parts of this test bench are: force sensor, linear displacement sensor, hydraulic cylinder, fixed metal base.

For the experiment, we use four research object:

1) shock absorber without composite spring and without hydraulic liquid;

2) shock absorber assembly with composite spring and hydraulic liquid;

3) shock absorber assembly with steel spring and hydraulic liquid;

4) shock absorber assembly with composite spring without hydraulic liquid.

\section{Test procedure}

One of research object install on the test bench and fixed for both ends. Shock absorber ends have spherical bearings. The force sensor and the linear displacement sensor with the hydraulic cylinder are connected to one end (the lower end), the other end (the upper end) is completely fixed. The test scheme is shown in the Figure 3. The kinematic perturbation action is applied to the bottom end by the hydraulic cylinder rod. The kinematic perturbation action has different strokes and frequencies [10], which are obtained by the simulation of the ATV moving along the different road types.

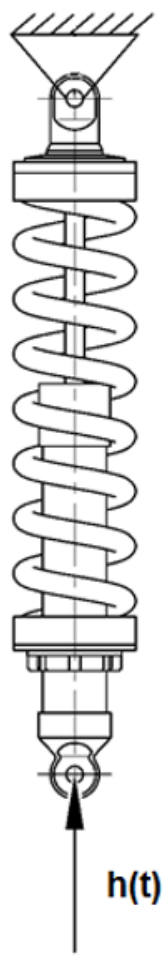

Fig. 3. Test scheme.

\section{Results}

The value of dry friction in the shock absorber seals was determined. The test data were processed using the method of robust locally-linear smoothing using the LOWESS algorithm [11]. The average value of dry friction in the shock absorber seals is $0.027 \mathrm{kN}$ (Figure 4). 


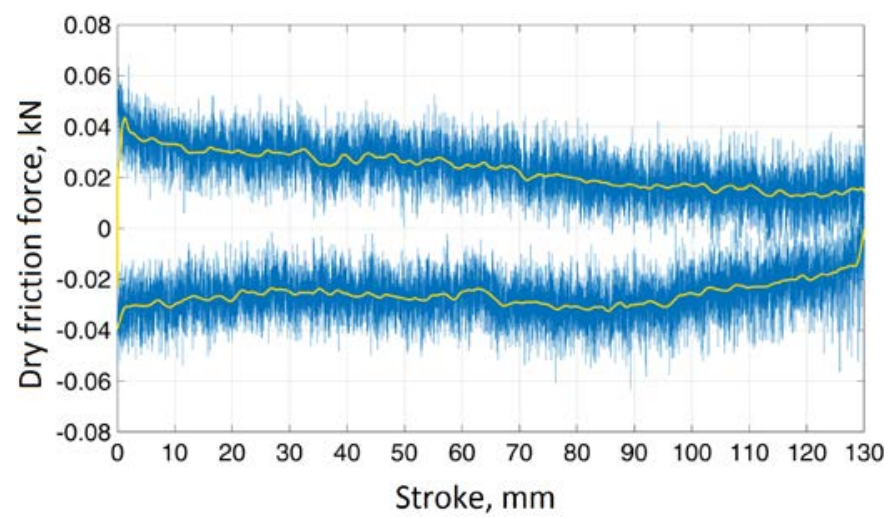

Fig. 4. Dry friction diagram.

Load-deflection characteristic of composite spring is shown in the Figure 5. This characteristic was obtained during testing shock absorber assembly with composite spring without hydraulic liquid. The shock absorber during this experiment is only a guide member. Characteristic plotted by blue line is the load-deflection characteristic of composite spring with considering dry friction in the shock absorber seals. Orange characteristic is only the characteristic of composite spring. Such characteristic has a hysteresis loop. The hysteresis loop results because the composite material has viscoelasticity properties. The value of the dissipated energy by the composite spring during single loading-unloading cycle shown in the Figure 5 is 7.261 Joules.

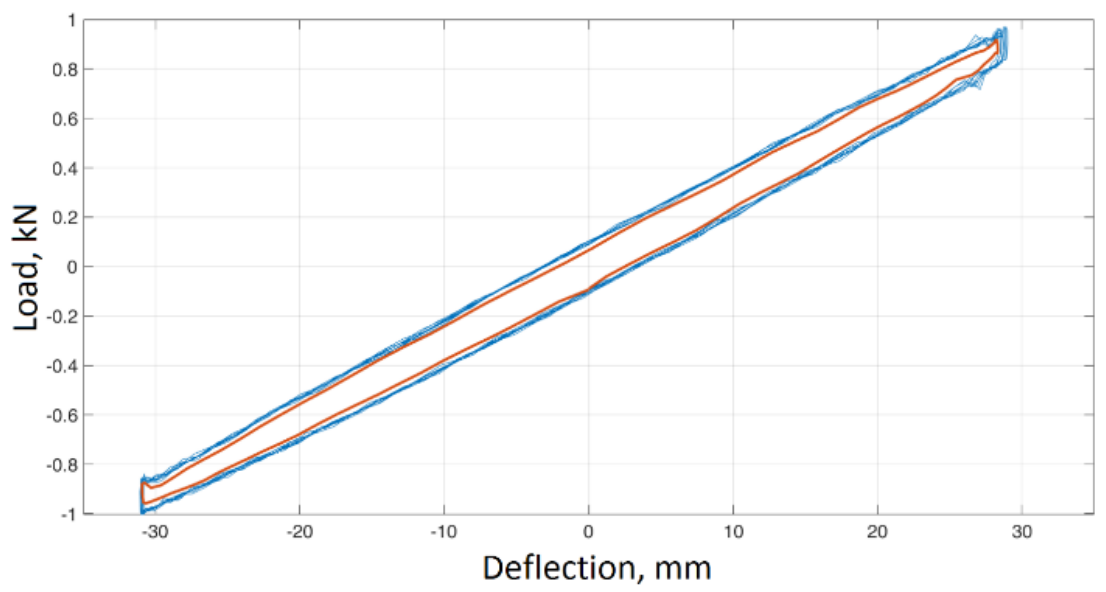

Fig. 5. Load-deflection characteristic.

The hysteresis loop depends on deflection and frequency, so we need different combinations of spring deflection and perturbation frequency, but this research object has negative feature. When the shock absorber piston moves fast with high frequency, the air in the shock absorber body starts to throttle and the results become wrong.

To obtain satisfactory results, two identical test series were performed, but with two different research objects. The first object was shock absorber assembly with composite spring and hydraulic liquid and the second object was shock absorber assembly with steel spring and hydraulic liquid. The result diagrams of these tests are shown in the Figure 6. 
Shock absorber with the composite spring

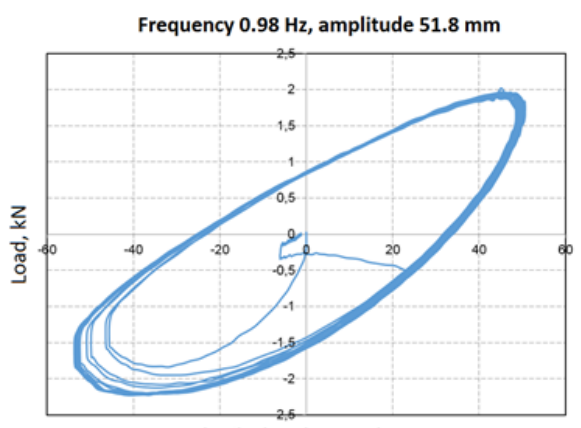

Shock absorber stroke, $\mathrm{mm}$

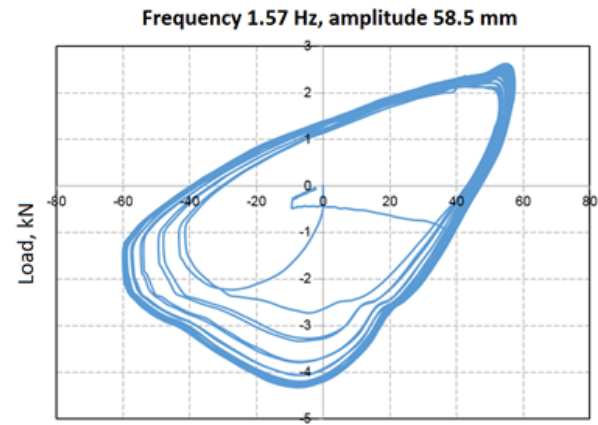

Shock absorber stroke, $\mathrm{mm}$

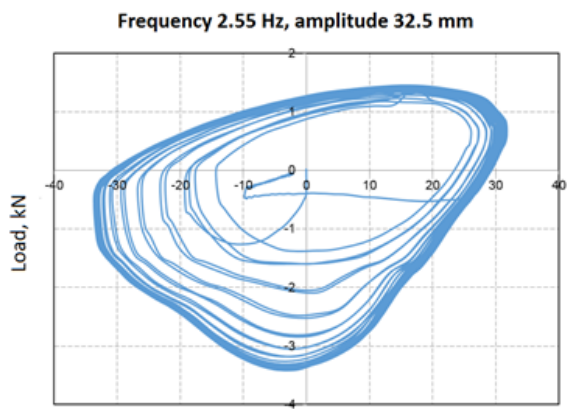

Shock absorber stroke, $\mathrm{mm}$

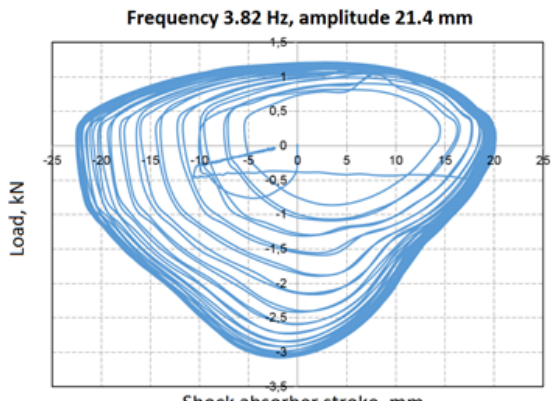

Shock absorber stroke, $\mathrm{mm}$

Fig. 6. Test diagrams.

\section{Shock absorber with the steel spring}

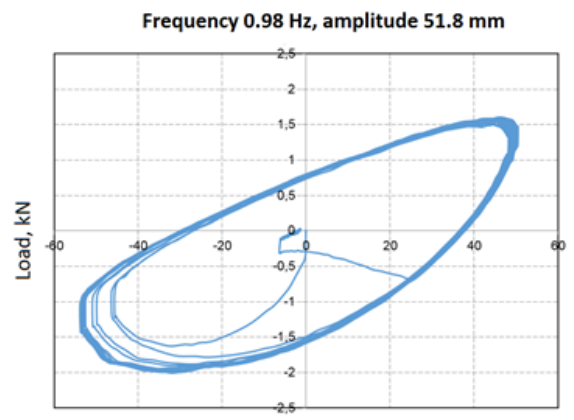

Shock absorber stroke, $\mathrm{mm}$

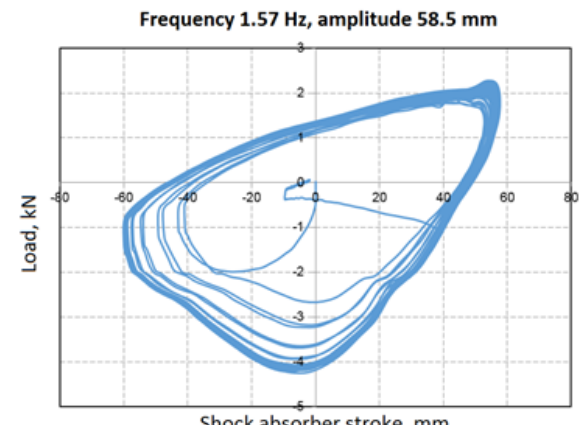

Shock absorber stroke, $\mathrm{mm}$
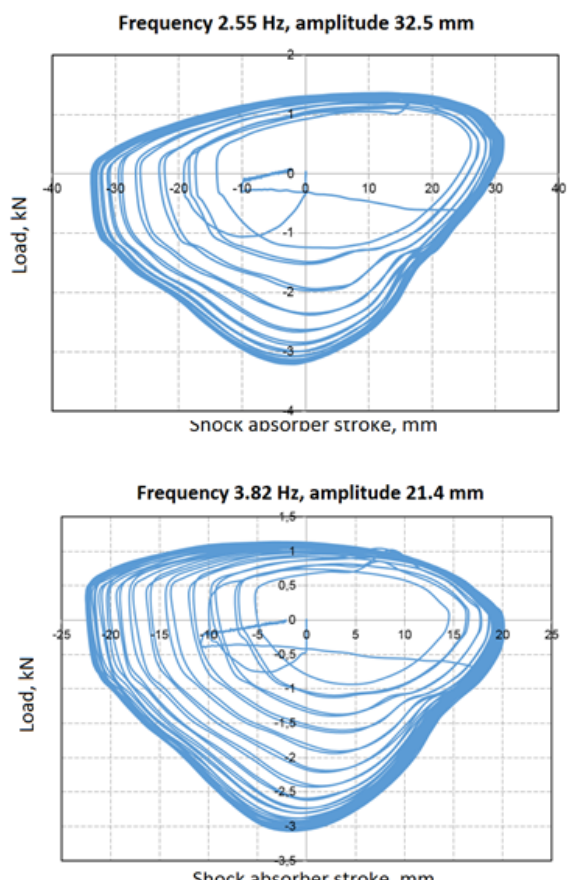

Shock absorber stroke, $\mathrm{mm}$ 
The damping properties of the composite spring material is also can be determined by relative energy units that have wide usage. The composite spring specific damping capacity may be defined as the energy loss per cycle ( $\Delta W_{d s p}$ ) divided by the pick potential energy

(U) and may be written as [12]:

$$
\psi d s p=\frac{\Delta W_{d s p}}{U}
$$

The loss coefficient or specific damping factor may be written as [8]:

$$
\eta_{d s p}=\frac{\Delta W_{d s p}}{2 \pi U}
$$

The stiffness of the composite spring is slightly different from the stiffness of the steel spring, so the diagrams have different shapes (Figure 6).

The diagrams show the transition zones, when the hydraulic cylinder of the test bench has not yet reached the steady-state test mode with a specified frequency and amplitude.

For further analysis of the tests, only the steady-state modes were used, when the shock absorber came to work with the specified amplitude. The steady-state mode diagrams are shown in the Figure 7.

The values of the dissipated energy for the first and the second research object were determined. If we take the losses in the steel spring equal zero, then we can calculate the dissipated energy by the composite spring only. These results are shown in Table 2, where $W_{d s p} A$ is the dissipated energy by the first object, and $W_{d s p ~} B$ is the dissipated energy by the second object;

$$
\begin{array}{r}
\Delta W_{d s p}=W_{d s p} A-W_{d s p ~ B} \\
n_{d s p}=\frac{\Delta W_{d s p}}{W_{d s p} B} \cdot 100 \%
\end{array}
$$

Table 2. The value of the dissipated energy and energy units for the composite spring hysteresis loop.

\begin{tabular}{|c|c|c|c|c|c|}
\hline \multirow{2}{*}{ Unit } & \multicolumn{5}{|c|}{ Value } \\
\cline { 2 - 6 } & $\begin{array}{c}0.98 \mathrm{~Hz}, \\
51.8 \mathrm{~mm}\end{array}$ & $\begin{array}{c}1.57 \mathrm{~Hz}, \\
58.5 \mathrm{~mm}\end{array}$ & $\begin{array}{c}2.55 \mathrm{~Hz}, \\
32.5 \mathrm{~mm}\end{array}$ & $\begin{array}{c}3.82 \mathrm{~Hz}, \\
21.4 \mathrm{~mm}\end{array}$ & $\begin{array}{c}5 \mathrm{~Hz}, \\
18.7 \mathrm{~mm}\end{array}$ \\
\hline$W_{d s p} A$ & $196.3 \mathrm{~J}$ & $449.7 \mathrm{~J}$ & $206.8 \mathrm{~J}$ & $125.7 \mathrm{~J}$ & $123.9 \mathrm{~J}$ \\
\hline$W_{d s p} B$ & $192.2 \mathrm{~J}$ & $436.8 \mathrm{~J}$ & $202.4 \mathrm{~J}$ & $122.4 \mathrm{~J}$ & $115.3 \mathrm{~J}$ \\
\hline$\Delta W_{d s p}$ & $4.1 \mathrm{~J}$ & $12.9 \mathrm{~J}$ & $4.4 \mathrm{~J}$ & $3.3 \mathrm{~J}$ & $8.6 \mathrm{~J}$ \\
\hline$n_{d s p}$ & $2.1 \%$ & $3 \%$ & $2.2 \%$ & $2.7 \%$ & $7.5 \%$ \\
\hline$\psi d s p$ & 0.102 & 0.251 & 0.27 & 0.48 & 0.63 \\
\hline$\eta_{d s p}$ & 0.016 & 0.04 & 0.044 & 0.077 & 0.12 \\
\hline
\end{tabular}



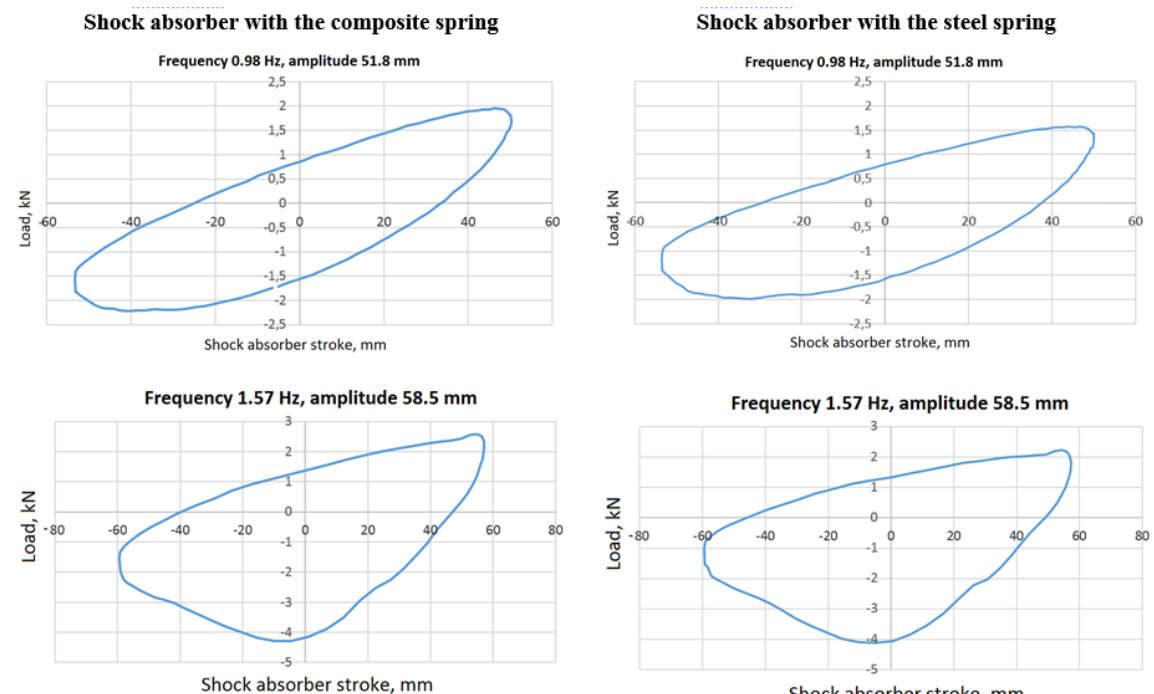

Shock absorber stroke, $\mathrm{mm}$
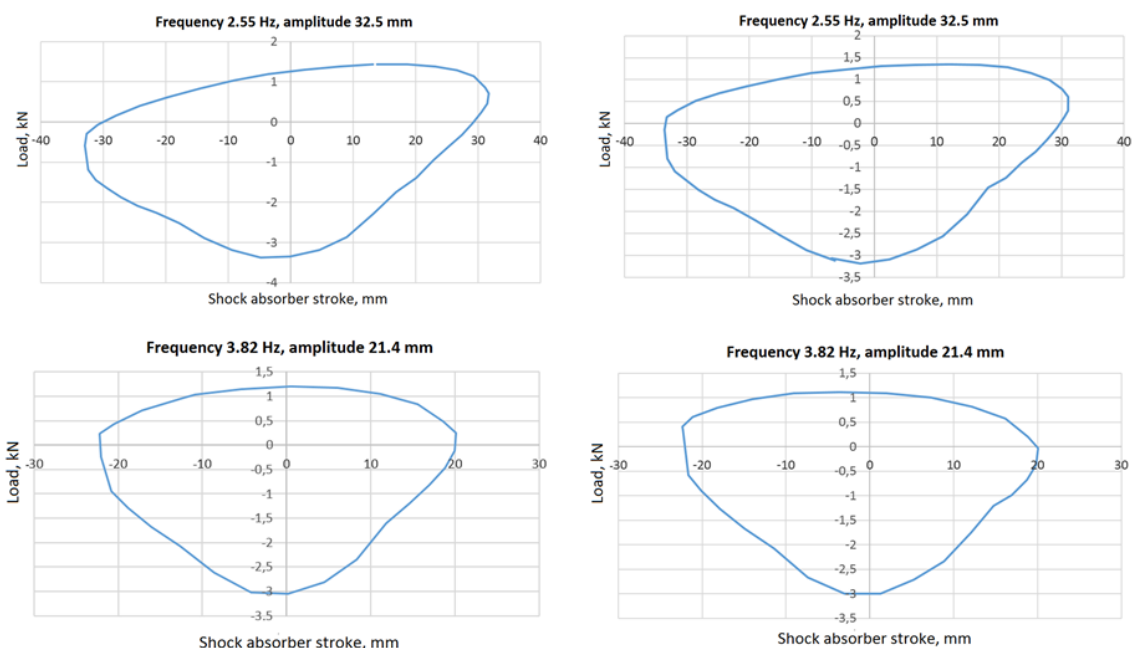

Fig. 7. Steady-state mode test diagrams.

\section{Conclusion}

The values of the dissipated energy by the composite spring determined during the experiment is significantly less than the shock absorber damping. However, the hysteresis damping is frequency independent unlike viscous Rayleigh damping, so the composite spring has better properties at high frequency perturbations. The maximum percent of dissipated energy in comparison with a shock absorber reaches $7.5 \%$. This value is comparable to the value of tire damping [13], therefore, the viscoelastic properties [14] of the composite spring should be taken into account when developing a refined simulation model of vehicle movement. 
It should be noted that the this work was carried out at the Bauman Moscow State Technical University, with financial support from the government represented by the Russian Ministry of Education under the project: \#14.577.21.0272. (Identification number: RFMEFI57717X0272)

\section{References}

1. B. A. Afanas'ev, I. Z. Dashtiev, Proektirovanie ehlementov avtomobilya iz polimernyh kompozicionnyh materialov (BMSTU, Moscow, 2006)

2. K.B. Evseev, A.B. Kartashov, Aktual'nost' primeneniya vintovyh pruzhin, vypolnennyh $s$ ispol'zovaniem polimernyh kompozicionnyh materialov, $v$ sistemah podressorivaniya sovremennyh avtomobilej, ZHurnal Avtomobil'nyh inzhenerov, \#4 (99), pp. 6-11, (2016)

3. Ruslantsev, A. N., Portnova, Y. M., Tairova, L. P., \& Dumansky, A. M. Analysis of mechanical properties anisotropy of nanomodified carbon fibre-reinforced woven composites, IOP Conference Series: Materials Science and Engineering, 2016, 153(1) doi:10.1088/1757-899X/153/1/012003

4. Chermoshentseva AS, Pokrovskiy AM, Bokhoeva LA. The behavior of delaminations in composite materials - Experimental results, IOP Conference Series: Materials Science and Engineering; 2016, DOI: 10.1088/1757-899X/116/1/012005

5. Kotiev, G.O., Padalkin, B.V., Kartashov, A.B., Diakov, A.S, Designs and development of Russian scientific schools in the field of cross-country ground vehicles building, ARPN Journal of Engineering and Applied Science, Vol. 12, Issue 4, 2017, pp. 10641071

6. V.V. Novikov, A.V. Pozdeev, A.S. Diakov, Research and testing complex for analysis of vehicle suspension units, Procedia Engineering, Vol. 129, pp. 465-470 (2015) DOI: 10.1016/j.proeng.2015.12.153

7. A.V. Pozdeev, V.V. Novikov, A.S. Diakov, A.V. Pohlebin, I.M. Ryabov, K.V. Chernishov, Reguliruemye pnevmaticheskie i pnevmogidravlicheskie ressory podvesok avtotransportnyh sredstv (VGSTU, Volgograd, 2013)

8. A.S. Diakov, V.V. Novikov Ehksperimental'noe issledovanie harakteristik pnevmogidravlicheskoj ressory dlya kolyosnogo shassi special'nogo naznacheniya, Gruzovik, \#7, pp. 7-11 (2015)

9. Novikov, V.V., Pozdeev, A.V., Diakov, A.S., Research and testing complex for analysis of vehicle suspension units, Procedia Engineering, 129, pp. 465-470

10. B.A. Afanas'ev Proektirovanie polnoprivodnyh kolesnyh mashin (BMSTU, Moscow, 2008)

11. https://www.mathworks.com/

12. Ahid D. Nashif, David I. G. Jones, John P. Henderson, Vibration Damping, (John Wiley \& Sons, Inc., New York, 1985)

13. N.N. Yacenko Pogloshchayushchaya $i$ sglazhivayushchaya sposobnost shin. Mashinostroenie, (Moscow, 1978)

14. Kobets, L. P., Malysheva, G. V., \& Borodulin, A. S. Rheological properties of system "elastomer binder-discrete carbon fiber", Inorganic Materials: Applied Research, 2016, 7(1), 15-19. doi:10.1134/S207511331601010X 